\title{
Sustainability Issues in Russian Housing Quality: Policy Implementations
}

\author{
Natalia Vlasova, Nikolai Smirnyagin \\ Ural State University of Economics, Yekaterinburg, Russia \\ *Corresponding author.Email: nat-vlasova@yandex.ru
}

\begin{abstract}
The article is devoted to assessing the role of housing and communal services while ensuring the socio-economic sustainability of the development of society. The work defines the position of the housing and communal services sector in the social sphere, analyzes the state support of the population in order to mitigate income inequality and regional differentiation of the standard of living as well as the cost of housing and communal services. The high social significance of housing and public utilities services leads to increased requirements for their quality. The analysis of trends in changing the approaches to the quality of housing services shows that at the moment, consumers and society impose new requirements: environmental friendliness, safety, rational use of resources, and therefore, the housing and communal services sector develops efforts and invests in improving the processing of municipal waste, water purification, and reliability of supply of resources to the population. The above stipulates the need for systematic research on the role and importance of the housing and communal services sector in ensuring the socio-economic sustainability of the society development.
\end{abstract}

Keywords: Housing and Communal Service, Housing Quality, Housing Policy, Local Sustainable Development, Housing Policy

\section{INTRODUCTION}

The methodology of this article is based on the following.

Firstly, it is the theory of sustainable development, factors and indicators of the sustainability of regions and cities.

Secondly, these are the theories of social services and the concept of the quality of housing and also of housing and communal services.

Thirdly, these are the aspects of regional inequality and state policy aimed at alleviating social inequality and regional imbalances.

Considering the theory of sustainable development, we focused on those studies in which the emphasis is placed on the provision of the population with housing and also housing and communal services, including the provision of such basic services as drinking water, sanitation, electricity, and heat supply. The affordability and quality of housing and also of housing and communal services is becoming an increasingly important agenda for state sustainability policies, and researchers propose new indicators to measure the level of housing sustainability [1, 2, 3, and 4]. It is no coincidence that the block on the indicators of the provision of the population with housing and communal services occupies an important place in the sustainability agenda [5, 6 , and 7$]$.

Paying attention to the quality of housing and also of housing and communal services, we note that this category is becoming more and more complicated and is largely related to the parameters of sustainability. Today, housing for many is not just a roof over their heads and the quality of housing in itself, but also a range of services that residents receive at their place of residence. Moreover, more and more demands are made on the quality of these services and their complication and diversification. The quality of drinking water, the possibility of sorting household waste, the quality of public spaces and the possibility of social communication, etc., are becoming more and more important for the population. [8] The relationship between housing quality and sustainability can be described in terms of resource consumption. Today, better quality housing services lead to more efficient and resource-saving consumption [9, 10, 11, and 12]. Water 
and heat meters are installed in houses; housing is built according to higher energy efficiency requirements, etc. In this article, we consider the quality of housing as a complex category, which also includes the quality of the provided housing and communal services.

Many researchers note that the availability of housing and essential resources remains an important problem [13], as well as spatial unevenness in the provision of housing and communal services [14]. Equality in all aspects is one of the most important indicators of sustainability. Significant differentiation of the population, as well as of the regions in terms of the level of housing and communal services provision, can become a threat to the sustainable development of the poorest regions and for the country as a whole. Therefore, it is important to identify the degree of interregional differentiation, as well as its dynamics (increase or decrease in the degree of differentiation), and also to develop government support measures, including subsidizing socially disadvantaged citizens and / or supplying organizations to increase the availability of these services and mitigate social and regional imbalances.

\section{MATERIALS AND METHODS FOR ASSESSING THE SOCIO-ECONOMIC ROLE OF THE HOUSING AND COMMUNAL SECTOR}

In the context of the tasks set out in this study, we focus on the above-mentioned issues. The hypothesis of the study is the statement about the possibility of increasing the socio-economic sustainability of the society development by increasing the effectiveness of public policy in the housing and utilities sector, as well as improving the quality of services in this sector.

In fact, a great variety of people's needs determines a wide range of services and, accordingly, the diversity of the industry division of this sphere, which also has no unambiguous idea in science about its structure.

Without discussing the task of formulating a definition of the service sector, we will introduce a working and most general definition of the service sector as an aggregation of economic sectors where products are viewed as services.

At the same time, since the service is mediated by the interaction of the producer, consumer and other actors, and its provision is regulated by a set of rules, the service sector can be interpreted, among other things, as a set of public relations, and the service itself as a public relation.

The analysis of scientific approaches in terms of the industry classification included in the service sector enables us to accept the housing and communal services as an industry constituent of this sphere.
It should be mentioned, that the aggregation of activities in the field of housing and communal services, includes not only the services themselves in the generally accepted sense (intangible, difficult to be isolated and inseparable from the source, synchronously rendered and received), but also activities that, by their content, can be attributed to work, according to the Civil Code of the Russian Federation. Thereby, the service criteria are normatively fixed in the Article 38 of the Tax Code of the Russian Federation: "An activity is recognized as a service for tax purposes, the results of which (1) have no material expression, (2) are realized and consumed in the process of carrying out this activity." The Article 702 of the Civil Code of the Russian Federation allows you to distinguish services from work by fixing the need for the contractor to hand over the result to the customer when performing the work, thus indicating the sign of the work tangibility, and the service intangibility (in this case, repair of something should be related to works, not to services).

It is worth implementing the criterion highlighted by $\mathrm{K}$. Marx - a service is a special use value "because it is useful not as a thing, but as an activity."

Actually there is a formation of a fundamentally different approach to the classification of social production spheres, where the social aspect is singled out as a criterion.

In its turn, describing the concept of "housing and communal services", let us concentrate on discussing the differentiation of the service sector and the social sphere concepts. The key discussion dilemma embraces the correlation of these concepts in terms of whether the service sector in general and the housing and communal services sector in particular should be determined by the increasing commercialization and thus be excluded from the social sphere.

Thus it should be noted that the uncertainty of the position in regard to the sphere of housing and communal services is actual not only in Russian science, this problem has an international aspect, while possessing institutional roots. In particular, applying to the international legal regulation, one can find a different interpretation of the place of housing and communal services in the social sphere.

Studying the Russian legislation, it should be pointed out that there is no uniformity in approaches to the qualification of services as social ones. Thus, the Federal Law No. 442-FZ "The basics of social services for Citizens in the Russian Federation" does not directly include housing and communal services to social services, however, when specifying this category of services in the Government Decree of the Russian Federation dated November 24, 2014 N 1236 "Approval of the approximate list of social services in accordance with the types of social services" the organization of 
"payment at the expense of the recipient of social services of housing and communal services" is classified as social services." Thus, the key law defining social services does not include housing and communal services as social ones. At the same time, we emphasize that exactly this regulatory legal act has fixed the possibility of providing social services by organizations of any organizational and legal form and ownership, as well as individual entrepreneurs, which allows the implementation of social services by the organizations operating in housing and communal services' activity.

At the same time, the Government Decree of the Russian Federation dated 05.09.2015 N 1738-r "Approval of the competition development standard in the RF regions", which is currently not in force, contains an attempt to modernize the social sphere by including a list of socially significant regional markets in its concept. Thereby the market of housing and communal services was classified as one of the socially significant markets among the Russian Federation regions.

The analysis of scientific works in the sphere of the ratio between the service sector and the social sphere enables us to state the lack of opinions' uniformity.

In fact, a canonical political economist A. Smith made a considerable impact on the discord in the analyzed context, referring the social sphere to the system of non-productive industries that do not produce material values. This approach was considered as the basis for numerous classifications focused on the division of industries into non-productive services and material production, thus, it led to the opinion, according to which the social sphere with its social services, was attributed to the service sector.

Concurring with the majority of scientists, we interpret the social sphere as a complex of branches of national economy aiming at the reproduction of human capital and the achievement of public welfare, the vast majority of activities in this sphere implemented in the form of services. It should be noted that in retrospect, the concepts of service sector and social sphere are distancing from each other, beginning to differ significantly from each other. In contrast to the Soviet interpretation, when the social sphere included education, healthcare, housing and communal services as well as science, tourism and personal services (non-productive sphere), merging these concepts; currently most authors agree that the service sector is broader and includes commercialized industries (tourism, personal services, catering, etc.).

We think that the concepts of social service and service in the social sphere are not identical. The definition of social service is given in Article 3, Federal Law No. 442: "social service is an action or activities in the field of social services to provide permanent, periodic, one-time assistance, including urgent assistance, to a citizen in order to improve his living conditions and (or) expand his ability to independently provide for his basic life needs", the essence being expressed in the phrase "assistance activities". Thus, services in the field of housing and communal services cannot be attributed to social services in the context of Federal Law No. 442. The gradual evolution of the service sector from providing social services to a limited circle of people in need to expanding both the spectrum and recipients of services in the social sphere and finally making them accessible to a significant part of society allows us to distinguish the above concepts. The denationalization of this sphere contributed to the expansion of the sphere under consideration and the range of social services. The key criterion for classifying a service as social seems to be the sphere of socially significant interests of the individual it satisfies. We consider a service in the social sphere to be social relations, when the needs of the individual in the development of human capital and potential are met, the quality of life ensured.

Thus, in the structure of the social sphere, we distinguish social assistance services (social services) and services in the social sphere, to which housing and communal services can be confidently attributed.

At the same time, formulating an approach to positioning the housing and communal services sector relative to the social sphere, we believe that strategic documents, giving the key directions of its development among the main goals, indicate improving the quality of life of citizens (for example, the National Security Strategy of the Russian Federation).

In turn, in normative legal documents improving the quality of life of the population is linked to ensuring the quality and comfort of housing. For example, in the Decree of the Government of the Russian Federation dated 31.12.2020 N 3683-r "On approval of the plan of legislative activities of the Government of the Russian Federation for 2021" Chapter IV "The development of social institutions and the improvement of the quality of life" is devoted to measures on improving legislation in developing the information component of housing and communal services, heat supply, in terms of upgrading the legal regulation of the general overhaul of common property in apartment buildings, etc.

At the same time, the Strategy for the Development of Housing and Communal Services in the Russian Federation for the period up to 2020 states the role of these services defining them as being of vital importance.

It should also be noted that the List of Required Socially Significant Regional and Municipal Services includes the service "applications and subsidies to citizens for housing and communal services", and since in our definition of housing and communal services, municipal and local authorities are indicated as subjects, 
this service can be fully attributed to the housing and communal services sector, although it is not the main one and the most characteristic.

The evaluation of the text of the Strategies of socioeconomic development of the federal districts also demonstrates social orientation of the housing and communal services sector, in particular, for example, among, its goals "social protection of low-income groups and ensuring economic accessibility of housing and communal services to the population" are indicated.

We will confine ourselves to the above references to acts of state authorities (their number is more than it is necessary to illustrate the author's position), demonstrating the place and role of housing and communal services in the social sphere.

Distinguishing between the service sector and the social sphere, we would like to stress that the latter has specific features: the presence of multi-channel financing, including public sources; the population as the sole recipient of social services; social services do not satisfy all needs, but only socially recognized ones; the social sphere is characterized by a high intensity of state participation in management and regulation. Thus, the concept of the social sphere is much narrower than the one of the service sector.

At the same time, contrary to the existing views on commercialization of housing and communal services and, accordingly, the retrospective decline in the social significance of this branch of the economy, a sufficient number of authors consider housing and communal services as part of the social sphere. Normatively, the attribution of housing and communal services to the social sphere is fixed in Article

40 of the Constitution of the Russian Federation by securing the right to housing and state support for this right. At the same time, the inelasticity of demand for housing and communal services causes state concern for citizens in this area. Also, the Strategy for the Development of Housing and Communal services in the Russian Federation for the period up to 2020 includes Chapter 7 devoted to social policy, emphasizing the social importance of housing and communal services and the need to take into account social factors.

\section{RESULTS AND DISCUSSION}

The social importance of housing and public utility services makes it possible to position this sector as one of the key factors of sustainable social and economic development of society. In particular, the dynamics of state subsidized housing and communal services and their reimbursement confirm the recognition of the public importance of this type of services and the need for their uninterrupted provision in order to ensure the quality of life (Figure 1; Table 1).
2400

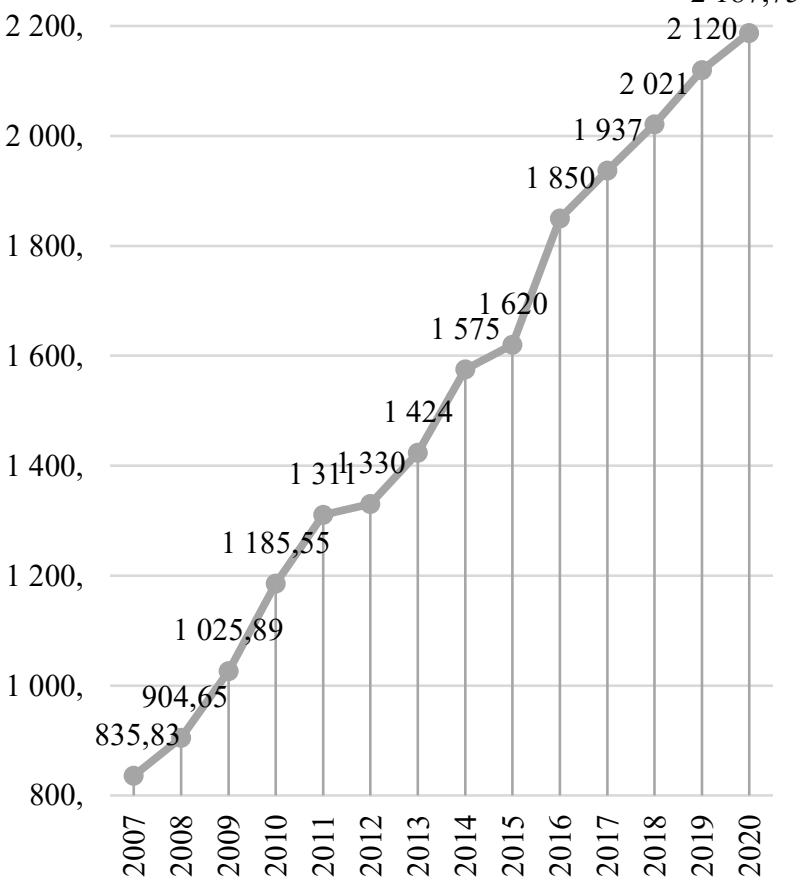

Figure 1 Average monthly subsidized housing and public utility services per family household, RUB [15]

Since the regional differentiation of living standards and the cost of housing and public utility services is quite significant, the state co-finances this sector (Table 1) in some regions of the Russian Federation in order to maintain the population's standard of living and quality of life, as well as to create a system of targeted support.

In the structure of household expenditure, the costs of housing services, water, electricity, gas and other types of fuel accounted for $11.1 \%$ [16], which exceeded the 2020 maximum permissible level stated in the Strategy for the Development of Housing and Public Utility Services in the Russian Federation.

It is worth noting that in the regions with high costs of housing and public utility services and difficult living conditions (e.g., low temperatures), the population bears a smaller proportion of costs. At the same time, the difference between regions can exceed $70 \%$. Figure 2 illustrates regions with the highest and lowest levels of charges for housing and communal services. 
Table 1. Reimbursement of population's expenses on housing and public utility services, \% [15]

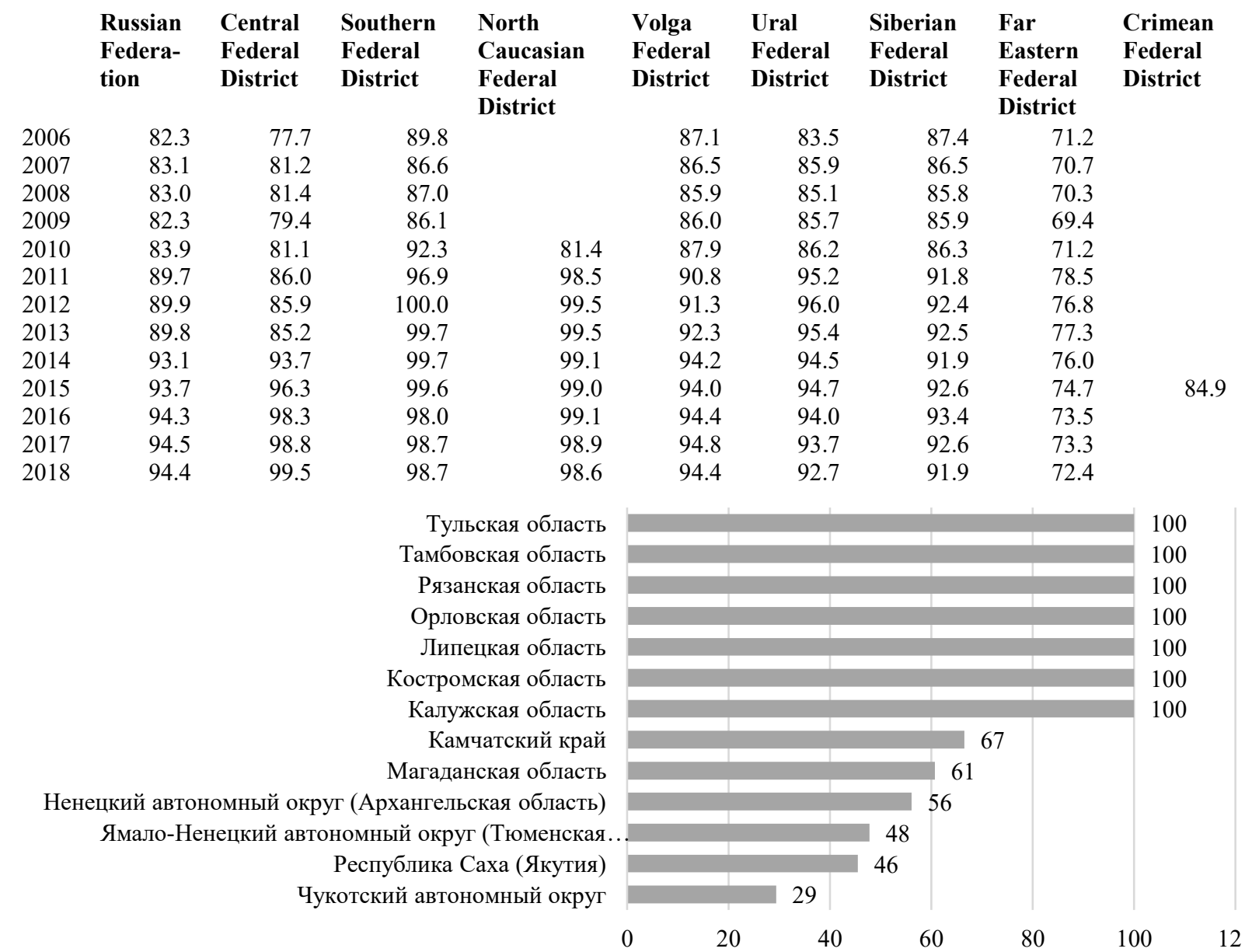

Figure 2 Regions with the highest and lowest levels of reimbursement of housing and public utility services, \% [15], where: Tula Oblast - Тульская область, Tambov Oblast -Тамбовская область, Ryazan Oblast - Рязанская область, Oryol Oblast - Орловская область, Lipetsk Oblast - Липецкая область, Kostroma Oblast Костромская область, Kaluga Oblast - Калужская область, Kamchatka Krai Камчатский край, Magadan Oblast - Магаданская область, Arkhangelsk Oblast - Архангельская область, Tyumen Oblast - Тюменская область, Sahka Republic (Yakutia) - Республика Саха (Якутия), Chukotka Autonomous Okrug - Чукотский автономный округ.

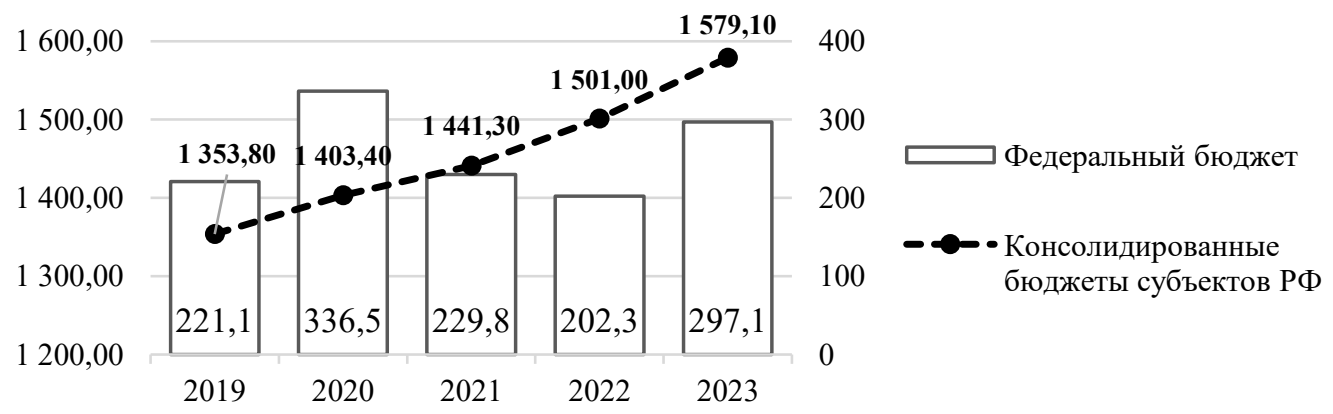

Figure 3 Implemented and planned budget allocations for financial support of housing and communal services costs, billion rubles [16], where Federal budget -Федеральный бюджет, Consolidated budgets of constituent entities of the Russian Federation - Консолидированные бюджеты субъектов РФ

The cited data of official statistics illustrate the state social policy in the sphere of housing and communal services, emphasizing the position of this sphere in the system of social relations, as well as the recognition of the public importance of housing and communal services. The scale of state support to the studied sector of the 


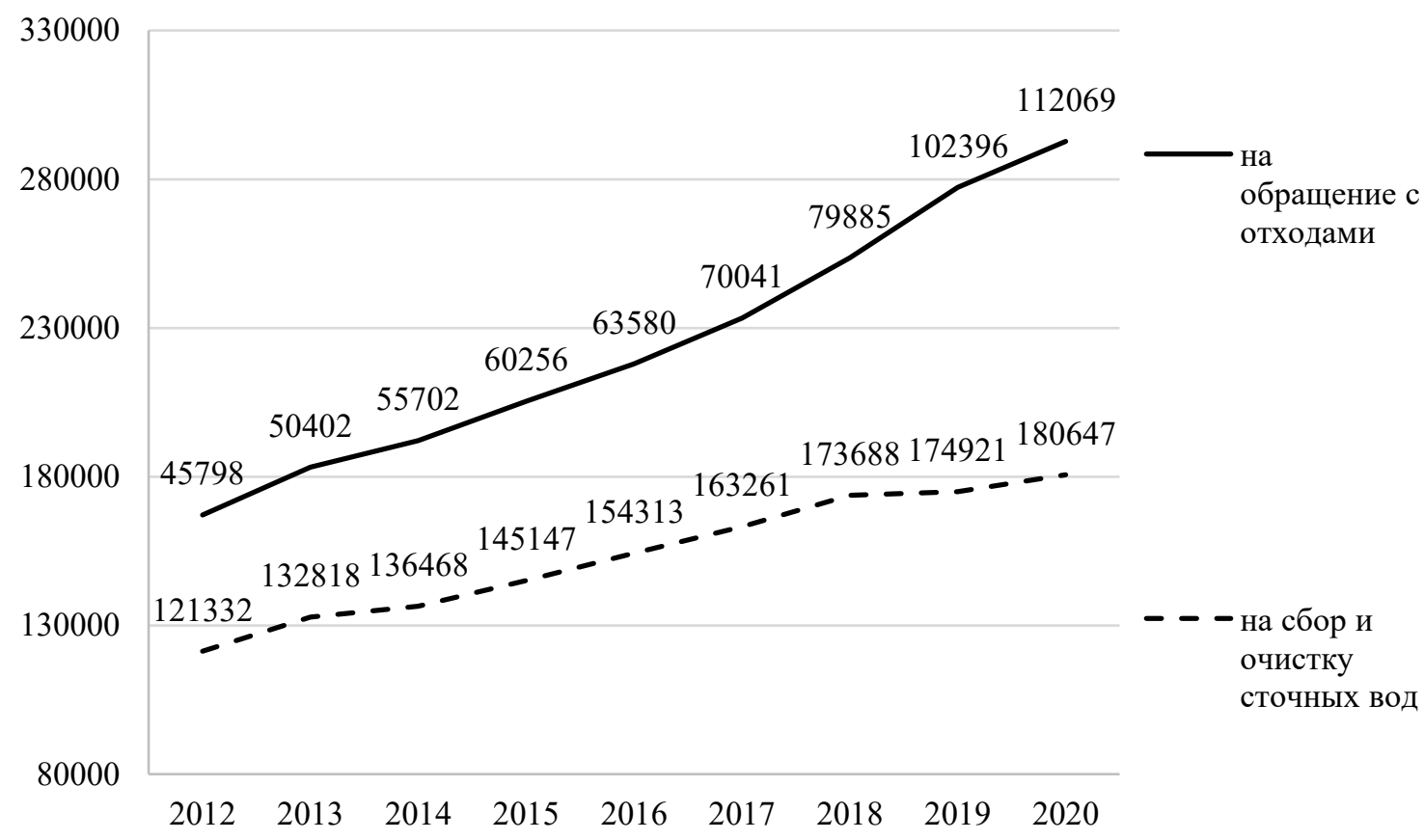

Figure 4 Current (operating) costs of environmental protection in the Russian Federation in actual prices, million rubles [17], where: ------ Costs associated with waste management - на обращение с отходами, - - - - - Costs associated with waste water collection and treatment - на сбор и очистку сточных вод.

economy can be demonstrated by the example of implemented and planned budget allocations for the financial support of housing and communal services (Figure 3).

The planned growth rates of budgetary allocations, according to the Ministry of Finance, should be $105.9 \%$ in real terms, while in 2021 it is planned to decrease the growth rates in both real and nominal terms $(92.6 \%$ and $96 \%$, respectively). In the structure of expenditures of the consolidated budget of the Russian Federation and the budgets of state extra-budgetary funds in 2020, the share of housing and communal services amounted to $3.8 \%$, which is less than health care and education, but more than culture, environmental protection or national security. In turn, the share of expenses in the overall structure of consolidated budgets was 8.5 , which is $0.6 \%$ less than in 2019.

It should be noted that the requirements for the quality of housing and communal services are retrospectively more complicated, which is due to the social significance and special characteristics of the service. Noncompetitiveness and practical non-exclusion, as well as trustworthiness dictate the need to introduce quality standards, including environmental friendliness, safety, reliability, rationality of the resource use. Because most of the services are provided within the framework of natural monopolies, the dependence of the properties of the service on the personal qualities of its producer decreases; however, with inelastic demand, the dependence of the consumer on the producer increases, which necessitates state regulation.

It should be noted that in the context of state policy, the housing and communal services companies are progressively developing the new approaches to the quality of services, conditioned by the requirements of environmental friendliness and safety (Figure 4).

At the same time, indicators of environmental safety in Russia as a whole demonstrate positive dynamics. In particular, the share of municipal solid waste sent for treatment in the total volume of generated municipal solid waste increased from $29.7 \%$ in 2019 to $38.1 \%$ in 2020 , while the share of municipal solid waste sent for recycling, in the total volume of generated solid municipal waste was $4 \%$ in 2020 .

\section{CONCLUSION}

It should be noted that in the context of the 2030 Agenda for Sustainable Development, adopted by the United Nations General Assembly on 25 September 2015 , the role of housing and communal services is undeniable. Among the goals of sustainable development of society set by the UN, the implementation of which is ensured, among other things, by services in the field of housing and communal services, one can mention such as: ensuring the availability and rational use of water resources and sanitation for all; ensuring universal access to affordable, reliable, sustainable and modern energy for 
all; ensuring openness, safety, resilience and environmental sustainability of cities and towns; ensuring the transition to rational patterns of consumption and production; reducing inequality within and between countries, etc.

It seems that the role of the state housing policy in ensuring the socio-economic sustainability of the development of society is realized in the following three aspects:

- social protection of the population, realized in the guaranteed provision of the necessary and socially conditioned minimum of housing and communal services;

- smoothing of regional differentiation of the standard of living and the cost of housing and communal services;

- changing approaches to the quality of resources and housing and communal services provided to the population by natural monopolies.

\section{REFERENCES}

[1] A. D. Jiboye, J. A. Adebayo, O. Adetayo, IJAERS, 7 (2020) p. 7.

[2] N. Winston, MP Eastaway, Soc Indic Res, 87, 2 (2008)

[3] K. G. Tiew, N. E. A. Basri, K. Watanabe, M. F. Abushammala, M. T. B. Ibrahim, J Mater Cycles Waste Manag, 17 (2015) pp. 3.

[4] A. Karji, A. Woldesenbet, M. Khanzadi, M. Tafazzoli, SCS, 50 (2019).

[5] A. D. Jiboye, Int J Humanit Soc Sci, 2 (2011) p. 1.

[6] A. I. Saidu, C. Yeom, SUSTAINABILITY-BASEL, 12 (2020) p. 2.

[7] H. Saldaña-Márquez, JM Gómez-Soberón, SP Arredondo-Rea, DC Gámez-García, R. CorralHiguera, Build Environ, 133 (2018).

[8] H. A. Bakir, J Environ Manag, 61 (2001) p. 4.

[9] R. M. Pulselli, E. Simoncini, FM Pulselli, S. Bastianoni, ENERG BUILDINGS, 39, 5 (2007)

[10] P. F. G. Banfill, A. D. Peacock, BUILD RES INF, 35 (2007) p. 4.

[11] A. Y. Lo, S. Liu, J Environ Manage, 214 (2018).

[12] J. X. Xiao, K. W. M. Siu, RESOUR CONSERV RECY, 131 (2018).

[13] M. Arman, J. Zuo, L. Wilson, G. Zillante, S. Pullen, Ecol Econ, 68 (2009) pp. 12.

[14] K. Gazzeh, IR Abubakar, UTIL POLICY, 52 (2018).
[15] Unified interdepartmental information and statistical system (EMISS) https://www.fedstat.ru/

[16] Federal State Statistics Service https://rosstat.gov.ru/

[17] Ministry of Finance of the Russian Federation. 